\title{
PENGEMBANGAN LKS PRAKTIKUM PADA POKOK BAHASAN LAJU REAKSI UNTUK KELAS XI SMA/MA MELALUI PENERAPAN GREEN CHEMISTRY (DI SMAN 31 JAKARTA)
}

Ade Irma Hifzhiah, Suwirman Nuryadin dan Darsef Darwis

Jurusan Pendidikan Kimia Fakultas Matematika dan IImu Pengetahuan Alam, Universitas Negeri Jakarta. Jl.

Pemuda No. 10 Rawamangun Jakarta Indonesia

\begin{abstract}
Abstrak
Penelitian ini bertujuan untuk menghasilkan bahan ajar dalam bentuk LKS praktikum pada pokok bahasan laju reaksi untuk kelas XI SMA/MA melalui penerapan green chemistry. Penelitian ini dilakukan pada bulan Februari hingga Juni 2012 di SMAN 31 Jakarta dan Jurusan Kimia, Fakultas Matematika dan Ilmu Pengetahuan Alam, Universitas Negeri Jakarta.

Metode penelitian yang digunakan adalah metode penelitian dan pengembangan, dengan analisis data secara deskriptif kualitatif. Penelitian ini terdiri atas 3 tahap yakni, studi pendahuluan meliputi studi literatur dan studi lapangan, Tahap pengembangan untuk mengevaluasi dan merevisi produk serta tahap pengujian bertujuan untuk mengetahui penerimaan produk pada masyarakat luas. LKS praktikum yang dikembangkan layak untuk dijadikan sebagai bahan ajar yang digunakan siswa sebagai panduan dalam kegiatan praktikum dengan memperhatikan beberapa aspek yakni: materi, bahasa, media, maupun penerapan green chemistry di dalamnya.
\end{abstract}

Kata Kunci: LKS, Eksperimen, Kegiatan Praktikum, Green Chemistry, Metode Pengembangan dan Penelitian

\begin{abstract}
This research has intended to develop Student Work Sheet for lab activities in XI senior high school of reaction rate subject by green chemistry applied. This research was done on February until June 2012 at JHS 31 Jakarta and Chemistry Department, Mathematics and Natural Science Faculty, Universitas Negeri Jakarta. This research used by Research and Development $(R \cap D)$ method with qualitative description approach. The method consists by three parts, there are: Preliminary Study is (literature study and observed) Next, Development Phase has for evaluated and revised about trial product $w$ Last, Experiment Phase is for knowing judgment's student about product. Based on the final testing, it has a conclusion that Student Work Sheet has acceptable for guiding students in lab activities by contained a few of aspects, there are: content, language, presented, and green chemistry concept.
\end{abstract}

Keywords: Student Work Sheet, Lab Activities, Green Chemistry, R n D method

\section{PENDAHULUAN}

Undang-Undang Sistem Pendidikan Nasional Tahun 2003 pasal 1 ayat 20 [1], menyebutkan bahwa pembelajaran adalah proses interaksi guru dengan siswa dan sumber belajar pada suatu lingkungan belajar. Menurut Depdiknas (2004) [2], pembelajaran kimia berkaitan erat dengan karakteristik ilmu kima sebagai produk (pengetahuan kimia yang berupa fakta, teori, prinsip, dan hukum) dan proses (kerja ilmiah). Karenanya, ilmu kimia dapat disimpulkan sebagai ilmu yang menggabungkan kemampuan penalaran dengan keterampilan atau proses yang diintegrasikan oleh lingkungan belajar, sehingga dapat memberikan pengalaman belajar yang baik bagi peserta didik. Selain itu, keduanya harus didukung kreatifitas seorang guru maupun kualitas sarana dan prasarana sekolah yang mumpuni agar kegiatan pembelajaran tepat sasaran.

Laboratorium sebagai penghubung dalam kegiatan pembelajaran di sekolah sangat berhubungan erat dengan penggunaan zatzat kimia. Pemilihan zat-zat yang tinggi kadar bahayanya juga turut mempengaruhi kesehatan para pelaku kimia yakni guru dan siswa serta lingkungannya. Menanggapi hal tersebut agar tercipta karakter kimia aman, 
menarik, dan menyenangkan diperlukan suatu metode atau pendekatan, yakni pendekatan green chemistry. Melalui pendekatan green chemistry selain memberikan suatu pembaharuan atau alternatif dalam pembelajaran kimia, di sisi lain dapat mengurangi jumlah bahan kimia yang dipakai maupun yang dibuang serta tidak mengurangi nilai atau esensi dari standar pengajaran yang diperlukan.

Utomo (2010:167) [3], pada prosiding seminar nasional (Green chemistry dengan Kimia Katalisis) menyebutkan green chemistry muncul karena adanya pergeseran paradigma tradisional suatu proses produksi yang hanya berfokus pada produk yang ekonomis tanpa memperhatikan limbah yang dihasilkan, menjadi berfokus pada produk yang secara ekonomis mampu mengurangi pemakaian bahan yang bersifat toksik atau berbahaya.

Kegiatan praktikum di laboratorium tidak terlepas dengan penggunaan Lembar Kerja Siswa (LKS) sebagai media atau sumber siswa untuk menuliskan atau memaparkan yang telah diamati. Penggunaan LKS akan lebih baik jika disusun langsung oleh guru bersangkutan agar tepat guna bagi kebutuhan para siswanya. Penelitian yang dilakukan oleh Wenno (2008:93) [4], menyebutkan bahwa penggunaan LKS keterampilan proses berbasis kompetensi dapat mempengaruhi respon dan minat dalam belajar fisika dengan presentase $85 \%$ dan dikategorikan berhasil.

Hasil analisis kebutuhan yang dilakukan di Sekolah Menengah Atas Negeri (SMAN) 31 Jakarta menyebutkan, bahwa sebagian besar siswa berpendapat menemui kesulitan pada penyampaian materi laju reaksi, hal ini disebabkan oleh beberapa faktor, diantaranya guru hanya menggunakan metode ceramah, penyampaian isi membosankan, penjelasan guru kurang dimengerti, dan banyaknya perhitungan dan hapalan. Selain itu, panduan atau bahan ajar dalam kegiatan praktikum hanya didukung oleh buku teks. Melalui data tersebut disimpulkan bahwa perlu adanya suatu inovasi bahan ajar praktikum pada pokok bahasan laju reaksi dengan pendekatan yang dapat dipahami dan menarik bagi siswa, agar saat kegiatan pembelajaran berlangsung tidak monoton dan membosankan.

Berdasarkan hasil pemaparan di atas, maka perlu adanya upaya yang dapat dilakukan untuk menangani kendala tersebut yakni, dengan mengembangkan bahan ajar bentuk LKS praktikum dengan pendekatan green chemistry pada pokok bahasan laju reaksi di SMA kelas $\mathrm{XI}$, agar kegiatan praktikum dapat berjalan secara maksimal.

\section{METODE PENELITIAN}

A. Metode Penelitian Metode yang digunakan dalam penelitian ini adalah metode penelitian dan pengembangan (Research and Development).

\section{B. Prosedur Penelitian}

Prosedur penelitian pengembangan ini berdasarkan pada tahapan-tahapan yang dikemukakan Brog dan Gall yang disederhanakan menjadi beberapa tahap [5], yaitu:

\section{Studi Pendahuluan}

Tahap ini bertujuan untuk :

a. Mengetahui kebutuhan dan kendala yang dihadapi siswa maupun guru dalam pembelajaran kimia terutama untuk materi yang memerlukan metode eksperimen atau kegiatan praktikum;

b. Mengetahui pendapat siswa dan guru tentang pembuatan LKS praktikum melalui pendekatan green chemistry;

c. mengidentifikasi kebutuhan dalam pembuatan LKS praktikum melalui pendekatan green chemistry untuk pembelajaran kimia.

Kegiatan yang dilakukan pada tahap ini diawali dengan melakukan tinjauan pustaka 
dari berbagai literatur yang memiliki relevansi dengan pengembangan bahan ajar yang akan disusun, kemudian melakukan analisis kebutuhan siswa dan guru melalui kuesioner instrumen analisis kebutuhan tentang LKS praktikum melalui pendekatan green chemistry sebagai pendukung pembelajaran kimia.

Tahap selanjutnya yakni pengembangan produk awal, pelaksanaan tahap ini memiliki tujuan untuk menghasilkan skenario LKS praktikum melalui pendekatan green chemistry sesuai dengan hasil analisis kebutuhan serta menghasilkan LKS praktikum melalui pendekatan green chemistry sebagai rancangan produk awal. Berikut kegiatan yang dilaksanakan pada tahap penyusunan produk:

a. Menelaah silabus pembelajaran berdasarkan KTSP dengan suplemennya.

b. Membuat analisis karakteristik materi pembelajaran materi Laju Reaksi.

c. Membuat rancangan LKS praktikum melalui pendekatan green chemistry.

Perangkat yang digunakan pada tahap ini adalah silabus, rancangan LKS praktikum melalui pendekatan green chemistry, serta program komputer.

\section{Pengembangan}

Tahap ini bertujuan untuk memperoleh informasi sebagai hasil evaluasi serta revisi LKS praktikum melalui pendekatan green chemistry. Kegiatan pada tahap ini adalah melakukan analisis evaluasi berupa pendapat atau kritik dari segala aspek yang meliputi materi, bahasa, media, maupun dari penerapan green chemistry yang akan dinilai melalui diskusi yang melibatkan guru dan dosen, dalam penyusunan LKS praktikum tersebut.

3. Pengujian

Pada tahap ini produk yang telah dikembangkan dan direvisi siap diuji ke lapangan, dengan menguji keterlaksanaan kegiatan praktikum dengan menggunakan LKS praktikum yang dikembangkan untuk mengetahui kendala-kendala yang ditemukan di lapangan.

\section{Teknik Pengumpulan Data}

Pada penelitian ini data-data yang diperoleh melalui serangkaian kegiatan yakni:

a. Observasi pembelajaran di kelas.

b. Kuesioner Analisis Kebutuhan (Guru dan Siswa)

c. Analisis keterlaksanaan LKS praktikum dalam pembelajaran kimia

\section{Instrumen Penelitian}

Instrumen penelitian yang digunakan yakni analisis kebutuhan siswa dan guru serta analisis keterlaksanaan LKS praktikum, dengan beberapa indikator yang dinilai yakni:

a. Substansi materi yang disajikan dalam LKS praktikum dengan pendekatan green chemistry harus memiliki relevansi dengan kompetensi yang disajikan didalamnya.

b. Penulisan Bahasa

c. Teknik penyajian

d. Desain tampilan/layout

e. Penggunaan huruf

\section{E. Teknik Analisis Data}

Pada penelitian ini data yang telah dikumpulkan kemudian dianalisis secara deskriptif kualitatif. Data kualitatif berbentuk deskriptif memiliki makna, yakni tangkapan atas perkataan subjek penelitian dalam bahasanya sendiri [6].

\section{HASIL DAN PEMBAHASAN}

Metode yang digunakan dalam penelitian ini adalah penelitian dan pengembangan (Research and Development) yaitu penelitian yang bertujuan untuk menghasilkan produk bahan ajar yang digunakan dalam proses pembelajaran. Tahapan-tahapan penelitian meliputi, studi pendahuluan (di dalamnya 
meliputi tahap analisis kebutuhan dan pengembangan produk awal), tahap pengembangan yang meliputi tahap pengembangan insturmen dan tahap pengembangan produk awal yang mencakup indikator yang akan dinilai oleh tim dosen dari segi materi, bahasa, kegrafikan (media) dan penerapan green chemistry dengan saran atau pendapat yang ditemukan pada LKS praktikum. Terakhir adalah tahap pengujian untuk mengetahui keterlaksanaan LKS praktikum yang telah dirancang.

Pada tahap studi pendahuluan peneliti mengkaji literatur mengenai penelitian yang telah ada sebelumnya mengenai LKS dan penerapan green chemistry untuk dijadikan tolak ukur pada penelitian ini. Kemudian, langkah berikutnya yakni analisis kebutuhan untuk mengetahui kebutuhan yang diperlukan guru untuk mengatasi masalah yang ditemui dalam kegiatan pendidikan atau pembelajaran serta mengetahui kebutuhan siswa dalam pembelajaran kimia terutama pada pokok bahasan laju reaksi. Serta penerapan green chemistry yang akan diterapkan pada kegiatan pembelajaran. Tahap selanjutnya adalah tahap perancangan yang terdiri: (1) Tahap perancangan terdiri atas kegiatan analisis karakteristik materi, pemetaan materi, dan perancangan isi dan tampilan bahan ajar. Tahap analisis karakteristik materi bertujuan untuk mengetahui pokok bahasan apa saja yang perlu ditampilkan dan lebih mendapat penekanan dalam pembahasannya yang merujuk pada hasil analisis kebutuhan siswa maupun guru. Berdasarkan analisis kebutuhan, pokok bahasan laju reaksi dirasa perlu ditampilkan dalam bahan ajar. Menurut Kurikulum Tingkat Satuan Pendidikan (KTSP) 2010, sub bab pokok bahasan laju reaksi meliputi: kemolaran dan faktor-faktor yang mempengaruhi laju reaksi.

Setelah menyusun kerangka materi, selanjutnya adalah membuat peta konsep dengan tujuan agar materi dapat disajikan secara terstruktur dan sistematis. Lalu mengembangkan bahan ajar dengan menggunakan berbagai literatur baik melalui buku teks maupun pencarian melalui internet seperti jurnal-jurnali ilmiah. Adapun isi LKS praktikum yang akan dikembangkan yakni pendekatan yang digunakan pada kegiatan praktikum disetiap percobaan yang dilakukan serta sumber-sumber pendukungnya.

Tahap selanjutnya adalah merancang tampilan. Untuk merancang tampilan awal LKS, peneliti melakukan observasi melalui dua LKS praktikum sebagai pembandingnya, yakni LKS praktikum mandiri yang dikembangkan oleh tim MGMP DKI Jakarta oleh CV Purnama dan LKS praktikum yang beredar dipasaran oleh Mastara. Setelah itu, peneliti menyusun tampilan yang akan disajikan dalam LKS praktikum dengan menyelami kekurangan yang ada pada kedua pembanding LKS tersebut.

(2) Tahap pengembangan awal bahan ajar dilakukan berdasarkan perencanaan bahan ajar. Aplikasi yang digunakan dalam penyusunan LKS praktikum adalah adobe photoshop untuk membuat disain awal halaman depan LKS dan Microsoft Word 2007 untuk mengetik teks atau isi pada LKS. Kertas yang digunakan untuk isi LKS berukuran A4 $100 \mathrm{gr}$ dan untuk cover digunakan glossy photo paper. Bahan ajar berupa LKS praktikum ini berisi: Identitas LKS, Peta Konsep, Lembar Data dan Keamanan Bahan, Aturan Keselamatan Kerja di Laboratorium, Kemampuan Alat-alat Dasar, Apa itu Green Chemsitry, Lembar For Your Information, Percobaan-percobaan yang menerapkan green chemistry, dan Glosarium.

Pada tahap pengembangan produk yang telah dihasilkan ini, sebelum dimanfaatkan 


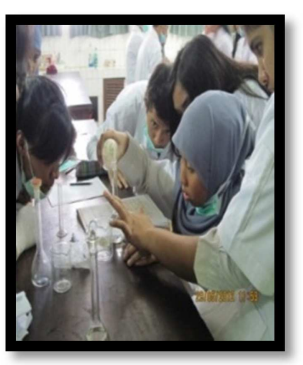

Gambar 1. Siswa sedan melakukan kegiatan pengenceran

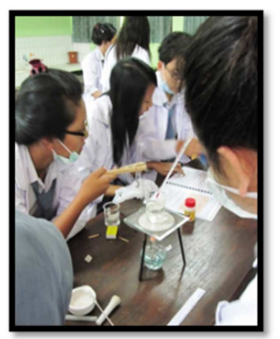

Gambar 2. Siswa sedang melakukan kegiatan pemanasan secara massal perlu dievaluasi terlebih dahulu melalui proses uji kelayakan. Uji kelayakan ini bertujuan untuk memperoleh masukanmasukan maupun koreksi tentang produk yang telah dihasilkan dari guru maupun dosen-dosen yang dianggap memiliki kredibilitas dalam penyusunan LKS praktikum ini. Uji kelayakan ini dilakukan melalui penilaian deskriptif kualitatif. Ditemukan beberapa perbaikan pada LKS praktikum yakni:

a. Keterlaksanaan LKS praktikum ditinjau dari isi (materi)

(1) Materi yang tersajikan dalam LKS praktikum telah sesuai dengan Standar Kompetensi dan Kompetensi Dasar yang ada pada silabus kimia 2011 yakni "Mendeskripsikan pengertian laju reaksi dengan melakukan percobaan tentang faktor-faktor yang mempengaruhi laju reaksi", (2) Prosedur dalam LKS praktikum masih ada yang membingungkan sehingga masih sulit untuk dipraktikkan, karena itu perlu adanya perbaikan, (3) Adanya perhitungan kimia yang tercantum dalam LKS praktikum ini, dapat digunakan siswa secara benar dan tepat, (4) Melalui pendekatan green chemistry kegiatan praktikum dirasa mengikuti perkembangan ilmu pengetahuan terkini (up to date), (5)
Adanya soal-soal dan tugas dapat memberikan nilai lebih bagi siswa untuk mengeksplorasi pengetahuan lebih dalam secara diskusi kelompok.

b. Keterlaksanaan LKS praktikum ditinjau dari bahasa

(1) Adanya kata-kata yang masih dianggap asing oleh siswa diberikan penjelasannya melalui lembar glosarium, sehingga siswa mengerti, (2) Bahasa yang digunakan pada LKS praktikum, cukup mewakili dengan tingkat kesesuaian berpikir siswa, (3) Ejaan atau tata kalimat yang digunakan masih belum tepat, ada yang kelebihan maupun kekurangan, seperti: kata kerja yang digunakan pada cara kerja sebaiknya disamakan semua (menggunakan kalimat aktif atau pasif), sehingga masih perlu diperbaiki, (4) Penggunaan istilah, simbol, atau ikon masih ada yang belum tepat dan perlu direvisi, seperti notasi untuk massa ditulis $g$ bukan gr.

c. Keterlaksanaan LKS praktikum ditinjau dari media

(1) Desain sampul kulit muka, punggung, dan belakang telah tampak baik dan konsisten dalam penyajiannya, (2) Untuk materi atau isi yang ada pada LKS praktikum cukup baik untuk tampilan warnanya. Namun masih ada halaman-halaman kosong yang dibiarkan saja, sehingga mungkin bisa dicantumkan informasi yang bersifat edukatif, misalnya, (3) Jenis huruf yang digunakan tidak berlebihan sehingga tidak menimbulkan kebingungan. Untuk judul menggunakan jenis comic sans MS dan is atau materi menggunakan arial, (4) Penempatan untuk judul, subjudul, teks, ilustrasi, keterangan gambar, dan nomor 
halaman cukup serasi untuk seluruh halaman.

d. Keterlaksanaan LKS praktikum ditinjau dari penerapan green chemistry

(1) Pada kegiatan praktikum menggunakan pereaksi dan pelarut yang murah dan ramah lingkungan, (2) Menjelaskan konsep-konsep green chemistry pada setiap percobaan, (3) Diskusi kelas mengenai isu-isu lingkungan (yang tertera pada halaman sampul belakang) sangat informatif dan edukatif bagi siswa, (4) Adanya halaman Lembar Data dan Keamanan Bahan sangat membantu siswa untuk bekerja hati-hati dengan bahan kimia yang digunakan, (5) Bahan yang digunakan merupakan bahan yang murah atau ekonomis serta ramah lingkungan yakni asam sitrat dan hidrogen peroksida dengan konsentrasi minimal.

Pada tahap pengujian Tahap uji coba ini dilaksanakan di SMAN 31 Jakarta dengan jumlah responden sebanyak 40 orang siswa kelas XI IPA. Tujuan dari tahap ini adalah mengetahui keterlaksanaan kegiatan praktikum yang telah dirancang sebagai bagian dari kegiatan pembelajaran kimia, khususnya pada pokok bahasan Laju Reaksi. Sebanyak 40 siswa kemudian dibentuk menjadi 5 kelompok yang akan melakukan kegiatan praktikum yang sesuai dengan prosedur yang ada. Kegiatan praktikum ini berlangsung selama 2 jam pelajaran $( \pm 90$ menit).

Kegiatan praktikum yang akan diuji coba memiliki 5 judul percobaan dengan sub pokok materi kemolaran dan faktor-faktor yang mempengaruhi laju reaksi. Melalui kriteria pendekatan green chemistry yang diterapkan dalam masing-masing percobaan, yakni melakukan eksperimen atau percobaan berskala mikro, artinya dalam eksperimen atau kegiatan praktikum menggunakan alat yang sederhana dan bahan yang relatif aman, ekonomis, dan ramah lingkungan, namun tidak mengurangi esensi dari kegiatan praktikum tersebut.

Kendala-kendala yang dihadapi saat kegiatan praktikum berlangsung yakni sebagian besar siswa yang belum paham dengan beberapa keterampilan dasar seperti teknik mengocok larutan, membaca skala larutan, serta memanaskan larutan yang benar. Sehingga melalui LKS ini diharapkan siswa lebih memahami teknik-teknik tersebut.

Berdasarkan analisis kuisioner yang diisi oleh siswa, dapat disimpulkan bahwa LKS praktikum ini telah layak digunakan sebagai media pembelajaran dalam kegiatan praktikum dengan pokok bahasan laju reaksi.

\section{KESIMPULAN DAN SARAN}

a. Kesimpulan

Berdasarkan hasil penelitian yang telah dilakukan maka dapat disimpulkan bahwa LKS praktikum yang dikembangkan layak untuk dijadikan sebagai bahan ajar yang digunakan siswa sebagai panduan dalam kegiatan praktikum dengan pokok bahasan laju reaksi melalui pendekatan green chemistry.

\section{b. Saran}

Masukan untuk pengembangan bahan ajar dalam bentuk LKS praktikum melalui penerapan green chemistry selanjutnya di jurusan kimia:

1. Melakukan upaya pengembangan bahan ajar melalui penerapan green chemistry pada pokok bahasan yang lainnya dengan menggunakan sampel dalam jumlah besar (lebih dari satu sekolah).

2. Melakukan pengkajian lebih lanjut mengenai efektivitas penggunaan bahan ajar melalui penerapan green chemistry sebagai alternatif media pembelajaran mata pelajaran kimia kelas XI SMA/MA. 


\section{UCAPAN TERIMA KASIH}

Pada kesempatan ini, penulis ingin mengucapkan terima kasih kepada:

1. Dr. Suwirman Nuryadin, M. Pd. dan Drs. Darsef Darwis, M. Si. selaku dosen pembimbing yang telah banyak membantu penulis dalam menyelesaikan skripsi ini.Kepala Sekolah, segenap staf, guru, dan siswa SMAN 31 Jakarta atas bantuan dan informasi yang dibutuhkan penulis dalam menyelesaikan skripsi ini.

\section{DAFTAR PUSTAKA}

[1] Republik Indonesia. Tahun 2003. Undang-Undang No. 20 Tahun 2003 tentang Sistem Pendidikan Nasional. Lembaran Negara RI tahun 2003, No. 20. Jakarta : Sekretariat Negara.

[2] Depdiknas. 2003. Kurikulum 2004 Standar Kompetensi Mata Pelajaran Kimia Sekolah Menengah Atas dan Madrasah Aliyah. Jakarta: Depdiknas.

[3] Utomo, M.P. 2010. Green chemistry dengan Kimia Katalisis. Prosiding Seminar Nasional Penelitian, Yogyakarta: hal 167-173.

[4] Wenno, I.H. 2008. Praktikum Fisika dengan Menggunakan LKS Competence Based Process Skills sebagai Alat Evaluasi. Jurnal Kependidikan. No.1, hal 93-110.

[5] Sukmadinata, N.S. 2010. Metode Penelitian Pendidikan. Bandung: PT. Remaja Rosdakarya.

[6] Agusta, I. 2003. Teknik Pengumpulan dan Analisis Data Kualitatif. Makalah disampaikan pada Pelatihan Metode Kualitatif di Pusat Penelitian Sosial Ekonomi. Bogor: Litbang Pertanian. 